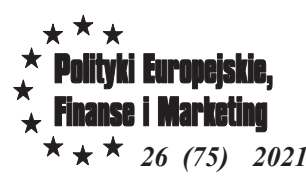

DOI $10.22630 /$ PEFIM.2021.26.75.13

\author{
Marek Wigier \\ Institute of Agricultural and Food Economics - National Research Institute \\ Marian Podstawka \\ Warsaw University of Life Sciences - SGGW
}

\title{
MEASUREMENT OF THE EFFECTIVENESS OF PUBLIC AID FOR FARMS IN POLAND
}

Agricultural policy is an attempt to put into practice the laws of economic theory, in order to achieve goals defined by the State. This research, carried out on a sample of four groups of Polish farms, contributes to the question of how to improve short-term economic policy in order to stimulate market mechanisms for the long-term development of the sector. Using data from the Polish FADN for 2008-2019, the authors of the study apply the modified PSM method to determine the economic effects of changes taking place on farms. The research indicates that effective investments are the source of long-term development and economic success. At the same time, it shows that economic entities, by optimizing their microeconomic objective function, adjust investments to the objectives of public aid, which reduces the effectiveness of the use of financial resources.

Keywords: efficiency of agricultural policy, investments in agriculture, farm development, agricultural policy.

JEL Codes: Q12, Q18, O13.

\section{Introduction}

The objective of agricultural policy, apart from solving ad hoc market problems, is to support the economic development of the agri-food sector and rural areas. Effective allocation of public funds to the activities of economic entities should lead to the maximization of multiplier effects. This result can be obtained by combining budgetary funds and spending private funds. Such a solution minimizes the risk of ineffective investments. Entrepreneurs who seek to maximize their primary goal, which is always profit (on farms - income), apart from the transfer of aid funds, should also consider the efficiency of investments in their economic calculations. The theory of rational expectations suggests that entrepreneurs (including farmers) willingly substitute more expensive sources of investment financing (e.g., commercial loans) with less expensive sources (e.g., state aid). Usually, however, the unfortunate effect of such support is to reduce the need for improved efficiency. Other economic entities, e.g., due to their reluctance for administrative procedures or to the need to make quick investment decisions, give up public aid, relying on market sources of financing or their own funds.

Contemporary nations commonly and with the use of significant financial resources undertake various types of intervention in the economy. A modern and well-defined agricultural policy should lead to the practical application of the laws disclosed by economic theory in achieving the goals set by the State. The choices made by the public 
sector, however, always determine manufacturers' decisions. They influence what to produce, how to produce, for whom to produce and how to make decisions, i.e., they influence the basic economic dilemmas.

Public authorities have a direct impact on the allocation of production resources and the redistribution of financial resources between farmers and entrepreneurs. However the extent of state interference in the economy is controversial, and views on intervention change over time, in line with the "pendulum theory". The Keynesian model of interventionism, which is a reaction to market imperfections, assumes that only the state can effectively influence the course of the business cycle and stabilize the economy. Liberals, on the other hand, believe that state institutions should be focused on achieving long-term goals, which means resigning from short-term economic regulation that disrupts the natural functioning of the market because it is counterproductive.

Considering the above, the aim of this article is to present the effectiveness of state aid in achieving the optimal allocation of available resources and the division of remuneration of production factors based on the FADN data. In the Paretsky sense, effective resource allocation is one in which it is impossible to improve someone's situation without making someone else's situation worse. This principle refers to individualistic values, i.e., whenever a change serves to improve the situation of some people without worsening the situation of others, it must be introduced. Most often, however, decisions made by the state relate to the necessity to make a choice, i.e., to improve the position of some people and diminish the position of others (for example by disturbing competitive balance or transferring money flows).

\section{Methodology}

To assess effectiveness of investments on farms financed with public funds, data from the agricultural accounting system of the Polish FADN was used. The PSM (propensity score matching) method was used to measure the net effect of investments in 2008-2019. In principle, this method consists of selecting two statistically similar groups of entities, the so-called experimental and control group, and then observing the changes that take place in the groups over time and assessing the impact of the applied "stimulus" on the changes taking place in both groups.

In the selection of the research sample, appropriately selected statistical methods were used. The aim was to equalize the "differences" between the observed groups and to bring the initial parameters to the maximally homogeneous state. Mathematically, the relations can be represented by the following formula:

where:

$$
\mathrm{Y}_{\mathrm{i}}=\mathrm{D}_{\mathrm{i}} * \mathrm{Y}_{1}+\left(\mathrm{D}_{\mathrm{i}}-1\right) * \mathrm{Y}_{0}
$$

$\mathrm{Y}_{\mathrm{i}-} \quad$ observed effect,

$\mathrm{Y}_{1}-$ effect in the case of implementing an intervention (i.e., using investment support programs),

$\mathrm{Y}_{0}-$ effect in the absence of intervention,

$\mathrm{D}_{\mathrm{i}}-$ presence of intervention $(1-$ there is, $0-$ there is not $)$ 
In this study, however, some extension and modification of the PSM method was made. Using statistical methods, a total of four different groups of farms were selected, i.e.:

- farms that have invested in development for at least 5 years, and have used public funds to co-finance these investments, from programs intended for investments in agricultural holdings for at least 3 years - they were called "farms with subsidies" for further purposes of the analysis;

- farms that have invested in development for at least 5 years, but have not cofinanced the investments with public funds from programs for investments on farms, they have only financed the investments for at least 5 years with commercial loans - they were called "farms with liabilities" for further purposes of the analysis;

- farms that have carried out investments for at least 5 investments, but have not financed them with subsidies from programs intended for investments on farms or a bank loan, but only with saved own funds - they were called "farms with equity" for further purposes of the analysis;

- farms without investments or those which have had them for a maximum of 1 year, financing them with public funds from programs intended for investments in agricultural holdings - they were called "farms without investments" for further purposes of the analysis;

Each of the above-mentioned groups consisted of about 80 farms. In total, 320 entities were included in observation and analysis. The subject of the assessment mainly concerned investments carried out under RDP 2007-2013 and 2014-2020.

\section{Results}

The standard production value (SO) of farms that were under observation in 2008 was relatively similar and ranged from approx. 40 to less than 50 thousand euro (Figure 1). After eleven years, i.e., in 2019, the difference in standard production between farms whose economic potential increased the most, i.e., "with subsidies", and farms "without investment", was doubled. In the other two groups, the value of the SO parameter increased, even though the increase was slight, and the difference between farms "without investment" and farms that invested using a bank loan for this purpose increased to approx. $22 \%$ (in favor of the latter). 


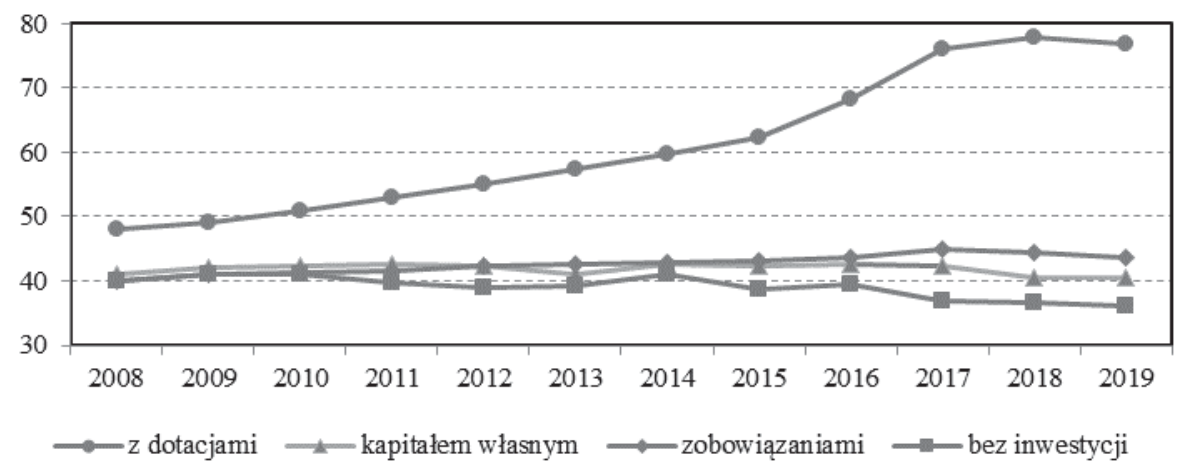

Figure 1. Average economic size of farms (in EUR thousand) Sources: Authors' own calculations based on the FADN data.

Ownership of agricultural land in the four analyzed groups of farms in 2008 was similar. They used an average of 30 to 34 ha (Figure 2). In 2019, the area of farms actively investing and benefiting from subsidies increased by approx. 50\% to 51 ha. In two groups, i.e., those investing on the basis of equity or with the use of a loan, the increase in the area of land used was small (2-4 ha), while in the group of farms "without investment", there was a total stagnation of the agricultural land owned.

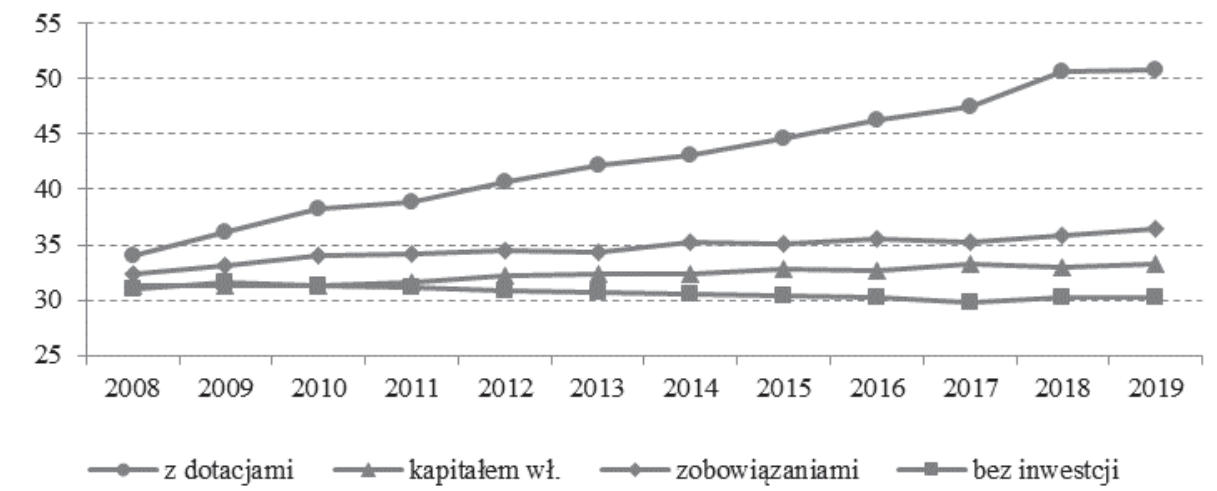

Figure 2. Average agricultural area per farm (in ha)

Source: Authors' own calculations based on the FADN data.

The nominal value of agricultural production in 2008-2019 increased in all analyzed groups of farms (Figure 3). However, the pace of the changes varied. On farms "without investment" it increased by only 19\% (to PLN 169 thousand), on farms investing on the basis of equity and on farms investing with the use of commercial loans there was an increase in production by approx. 60-70\% (respectively PLN 223 thousand and PLN 241 thousand). As expected, the highest (by 244\%) increase in production value took place on farms in the group "with subsidies". It reached 488 thousand PLN, with a clearly outlined growing trend in 2016-2019. This means that farms actively 
investing at least doubled the value of market production, while the remaining farms at most retained their shares.

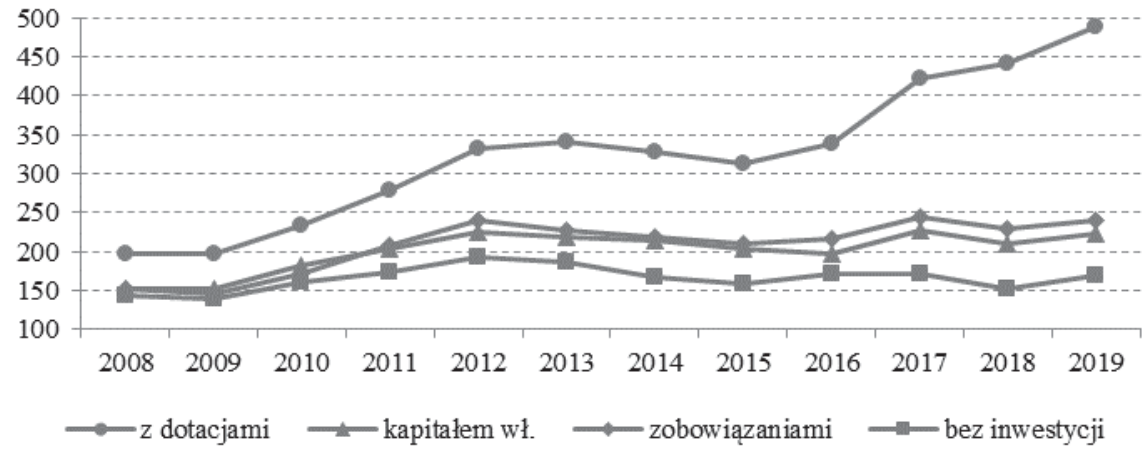

Figure 3. Average value of total production per farm (in PLN thousand)

Source: Authors' own calculations based on the FADN data.

Increase in production value was also accompanied by a proportional increase in its costs. On average, they increased by $57 \%$. The highest increase in production costs (by $135 \%$ ) took place in the group of farms "with subsidies" (Figure 4). In the other two groups, i.e., those investing on the basis of a commercial loan and in the group financed only with equity, the costs increased by $52 \%$ and $32 \%$, respectively. The smallest (only by $7 \%$ ) was the increase in the costs in the group of farms "without investment". The increase in costs resulted primarily from increased scale of production resulting from increased acreage of crops, as well as the application of new cultivation and breeding techniques based on the investments made.

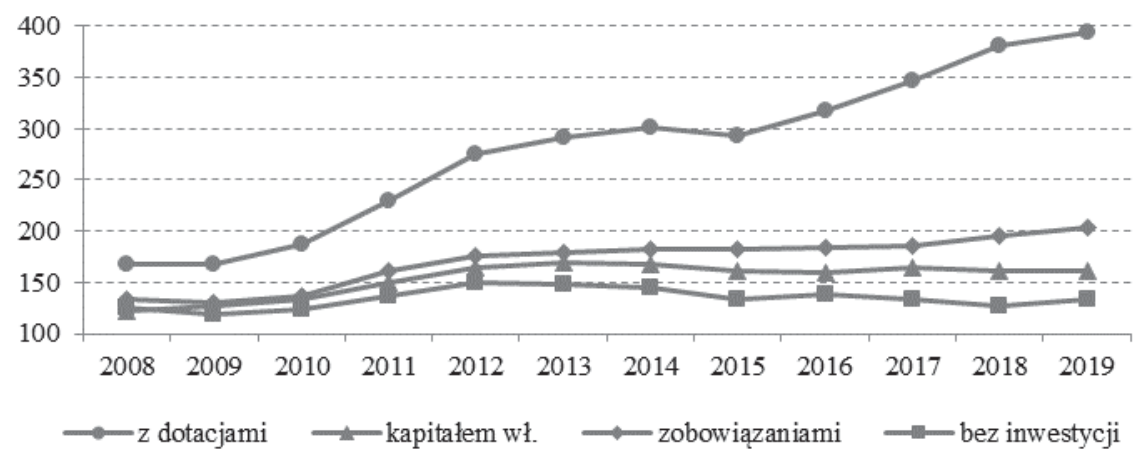

Figure 4. Average value of total production costs per farm (in PLN thousand) Source: Authors' own calculations based on the FADN data.

Analyzing total investment expenditure and changes in the value of long-term liabilities brings us closer to the problem of assessing effects of state aid in agriculture. The largest investment outlays (100-150 thousand per year) were incurred in 2008-2019 by farms belonging to the group "with subsidies" (Figure 5). The expenses were also strongly correlated with the cyclical nature of the rural development programs 
implemented in 2007-2013 and 2014-2020. In the periods at the beginning of the implementation of the programs, or at the end of their implementation (or at the end of the call for proposals in subsequent rounds), the value of investments was lower by approx. PLN 40 thousand in relation to other periods. It can be simplified to say that it was an amount approximately equal to the value of the subsidy received. Significantly lower investments (ranging from PLN 20,000 to PLN 60,000 per year) were carried out by farms from groups financed with "equity" or with "liabilities". We can also observe a delay of the investment peak period in these two groups, as compared to the peak investment period of farms using public subsidies by approx. two years. This attitude results, among others, from the expectation of lower prices (or more favorable offers from machine dealers) dictated by lower demand from farmers waiting for new aid programs. Farmers investing on the basis of equity, or a commercial loan, often purchase fully functional equipment on the secondary market because of its lower prices. The investment "delay" and lower investment value are also the result of rational assessment of needs and monitoring of investments in farmers who received the subsidy, and then imitating them.

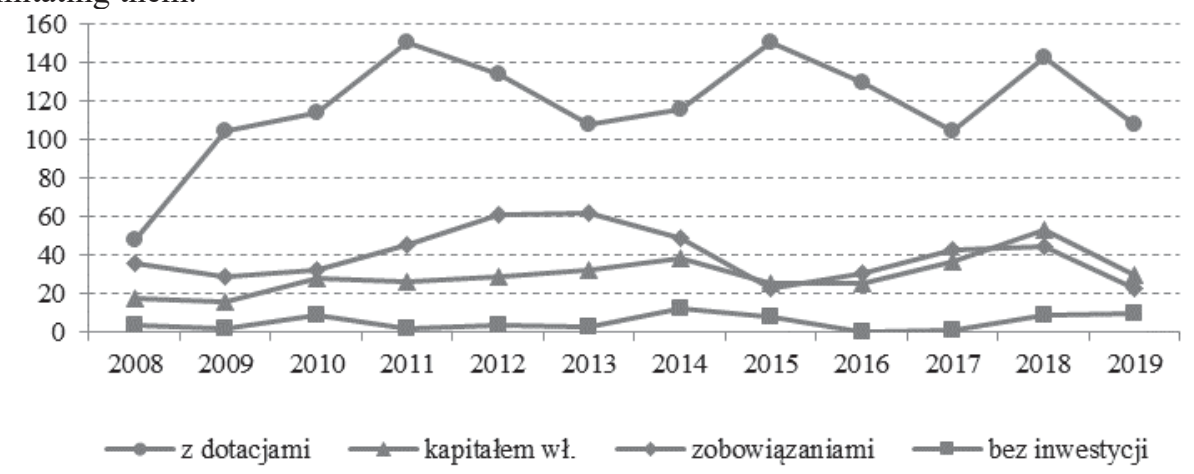

Figure. 5 Average value of expenditure on investment activity per farm (in PLN thousand) Source: Authors' own calculations based on the FADN data.

Conducting capital-intensive investments, co-financed by public aid, farms often take out long-term bank loans. The consequence of this is a disturbingly high increase in the value of long-term debt per farm from approx. 60 thousand PLN up to nearly 270 thousand PLN (Figure 6). This increase (by approx. 90\%) can specifically be observed in 2014-2016. Investments in this period were often forced by the need to buy additional equipment, which was not financed from the RDP funds, but was necessary for the completion of investments financed by public aid. Another reason may be farmers taking so-called "loans for loans"; that is, financing debt servicing with external funds to maintain financial liquidity. In the group of farms financed only with external capital (without the participation of public funds), we can observe the maintenance of a constant debt at a relatively stable level of approx. 60-90 thousand PLN depending on the year. On the other hand, in the group of farms with "equity", we can see a clearly outlined trend of slow reduction of long-term debt. Owners of the farms systematically pay off the debts incurred in previous years. They also do not see the need for further investment 
in development, and maybe even think about the cessation of commercial agricultural production, similar to farmers from the group of farms "without investment".

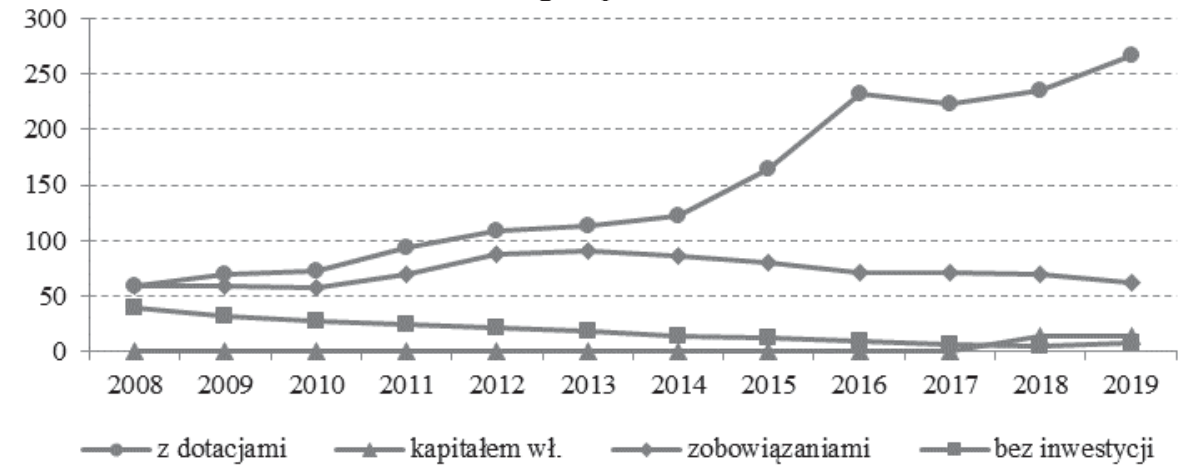

Figure 6. Average value of long-term liabilities per farm (in PLN thousand) Source: Authors' own calculations based on the FADN data.

The investments carried out in 2008-2019 resulted in the development of most farms, a change in their economic potential and production value, and consequently also a change in the level of income (Figure 7). Even though these changes were not identical in all groups, their direction was similar, determined mainly by macroeconomic market factors. In general, the average income for the entire population in 2019 doubled, as compared to 2008. The highest increase in income (by $172 \%$ to PLN 182 thousand) concerned the group of farms "with subsidies". In the remaining three groups, the income growth was similar. At the end of the observation period, income in all the groups was approximately $70-90 \%$ higher. However, the distance between the highest (farms "with subsidies") and the lowest income (farms with "no investment") widened. The income was respectively $152 \%$ higher (by $63 \%$ in 2008).

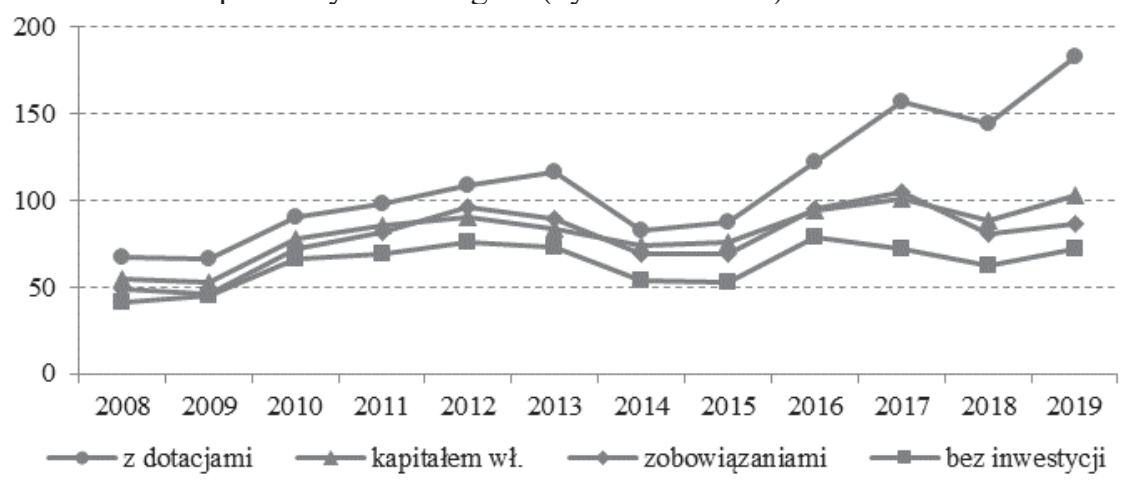

Figure 7. Average income per farm (in PLN thousand)

Source: Authors' own calculations based on the FADN data.

When assessing the effectiveness of public aid, the value of total income obtained in each of the analyzed groups of farms was converted into basic economic factors of production, i.e., labor, land and capital. The obtained results prove that after converting 
farm income to a full-time employee, it increased in all analyzed groups (Figure 8). This indicates both the good economic situation on agricultural markets in this period and its skillful use by all groups of farms. Nominally, however, this increase was varied. The highest (by approx. 160\%) occurred in the group of farms "with subsidies" (from PLN 34 thousand to PLN 87 thousand), the lowest (by approx. 74\%) in the group "with liabilities" (from PLN 26 thousand to 45 thousand PLN). However, the lowest income per full-time employee throughout the entire period was maintained by farms "without investment" (approx. PLN 44 thousand in 2019). In the initial period of the analysis, the difference in income between the group of farms with the highest income ("with subsidies") and the group with the lowest income ("without investments") reached 48\% in favor of the former, and in 2019 it increased to $93 \%$. The distance separating the group of farms "with subsidies" from the other groups remained unchanged for most of the analysis period but increased significantly in 2017-2019. The data proves that investments carried out by farms using state aid funds contributed to the increase in agricultural income in 2019 to a level exceeding by approx. $45 \%$ the value of the average income in the national economy. In the "equity" group, this income only approached the level comparable to the average income in the economy, and in the remaining groups it will not reach this level.

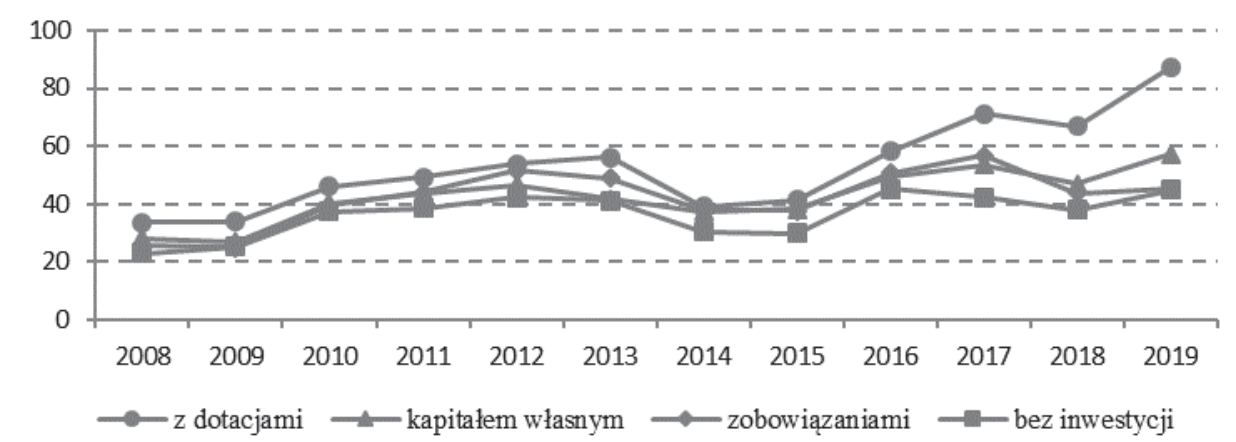

Figure 8. Average income per full-time employee (in PLN thousand) Source: Authors' own calculations based on the FADN data.

The comparison of the amount of income per ha of agricultural land does not indicate such obvious trends (Figure 9). The difference between the group of farms with the highest and the lowest income per ha ranged from $10 \%$ in 2013 to $55 \%$ in 2019 . For six years the highest income was reported by farms "with subsidies", for five years farms from the group "with equity", and in one year - farms financing their development mainly on the basis of commercial loans. The lowest income per ha of arable land was recorded by farms from the group "without investment" throughout the entire period. 


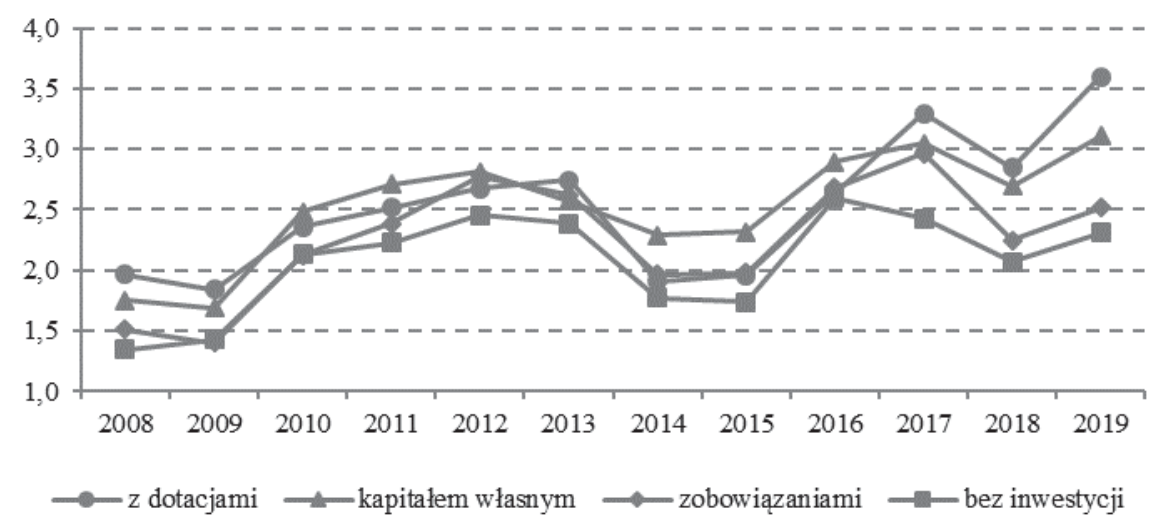

Figure 9. Average income per ha of agricultural land (in PLN thousand)

Source: Authors' own calculations based on the FADN data.

The analysis of the amount of income per PLN of a full-time employee proves, however, that the rapid growth of the production potential based on the significant involvement of "easy" external capital does not guarantee the highest efficiency of its use. Farms financing investments mainly with subsidies decreased their income in 2019, as compared to 2008 , by as much as $30 \%$. The situation continued throughout the observation period. Decrease in income (by approx. 15\%) also concerned the group financing its development only with equity, and the group of farms without investments. Only the group of farms "with liabilities" maintained the status quo from 2008 in 2019 (Figure 10). In conclusion, it can be stated that incorrectly planned investments usually bring a decrease in the effectiveness of the capital employed. In the group of farms "with subsidies", reduction of this ratio is also influenced by the high value of long-term liabilities.

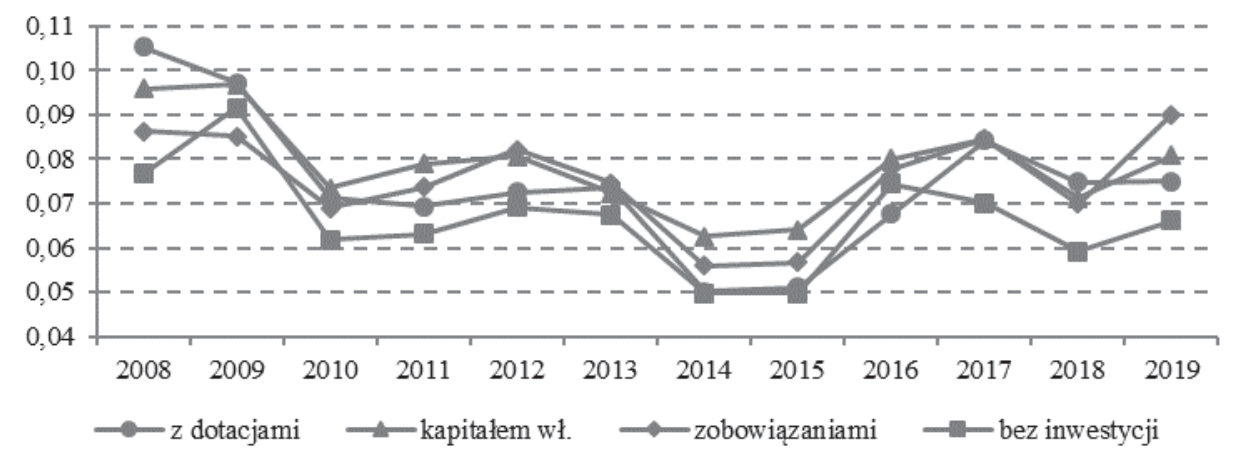

Figure 10, Average income per PLN of total assets (in PLN thousand)

Source: Authors' own calculations based on the FADN data. 


\section{Conclusions}

Analyses carried out for four groups of farms show that well-planned investments are the decisive factor of economic success. This means implementing a development strategy that is optimal for maximizing achievement of goals, and considering the available possibilities. An investor - that is a farmer - when making investment decisions, should not be guided by choices of other entities (should not imitate others), but rather make a reliable assessment of the situation to increase their own efficiency. The optimal allocation of resources is related to the utility of proper capital allocation. The conducted research shows that the so-called flight "forward" and large investment expenditures do not always bring the desired economic effect. Choosing an investing strategy is much more complicated. This is reflected in the less obvious economic effects after considering the obtained effects in relation to the incurred financial outlays.

Research shows that development is inseparable from investment. State aid accelerates investments and modernization activities on farms, which results in the modernization of production techniques and technologies, structural changes, and commercialization of farms. Farms that are modern and well-equipped, thanks to public aid, significantly increased their production and economic potential in 2008-2019. This is mainly reflected in a significant increase in their productive and economic potential as well as in income per full-time employee.

In the involvement of public funds in private activities, we can observe the socalled the "crowding out" effect, which consists in replacing own funds or bank loans with aid from public sources. Obtained subsidies often prompt beneficiaries of aid programs to evaluate the profitability of investments in a less thorough manner (since we have public funds, it would be a "sin" not to take them). Without public support, some investments consisting in the purchase of machinery and equipment would be implemented, but their scope would be much smaller, and they would be spread over a longer period. State aid accelerated investments and modernization activities, which resulted in a significant modernization of production techniques and technologies.

\section{Bibliography}

Adamowicz M., Ewolucja i impact assessment jako sposoby oceny interwencji publicznych ze środków Unii Europejskiej [Evolution and impact assessment as methods of assessing public interventions from the European Union funds], [in:] Agroekonomia w warunkach rynkowych. Problemy i wyzwania [Agroeconomics in market conditions. Problems and challenges], (ed.) Grzelak A., Sapa A., Zeszyty Naukowe UE in Poznań, 2010,

Carolyn H., Maffioli A.,Vázquez G., A Primer for Applying Propensity-Score Matching, InterAmerican Development Bank, 2010,

Chavas J.-P., Aliber M., An Analysis of Economic Efficiency in Agriculture: A Nonparametric Approach, Journal of Agricultural and Resource Economics, Vol. 18, No. 1, 1993,

Podstawka M., Finanse. Instytucje, instrumenty, podmioty, rynki, regulacje [Finances. Institutions, instruments, entities, markets, regulations], PWN, Warsaw 2017,

Stiglitz J.E., Ekonomia sektora publicznego [Economics of the public sector], PWN, Warsaw 2004,

Wilkin J., Teoria wyboru publicznego - homo oeconomicus w sferze polityki [Public choice theory - homo oeconomicus in the sphere of politics], [in:] Wilkin J. (ed.) Teoria wyboru publicznego. Wstęp do ekonomicznej analizy polityki i funkcjonowania sfery publicznej [Public 
Choice Theory. Introduction to the economic analysis of politics and the functioning of the public sphere], Wydawnictwo Naukowe SCHOLAR, Warsaw 2005,

Wigier M., Alokacyjne i dystrybucyjne dylematy polityki rolnej na przykładzie polskiego sektora rolno-spożywczego w okresie 1989-2018 [Allocation and distribution dilemmas of agricultural policy on the example of the Polish agri-food sector in the period 1989-2018], Studia and monographs No. 174, IERiGŻ-PIB, Warsaw 2019.

\section{Pomiar efektywności pomocy publicznej dla gospodarstwach rolnych w Polsce}

\section{Streszczenie}

Polityka rolna jest próbą praktycznego zastosowania praw ujawnionych przez teorię ekonomii dla osiągnięcia celów określanych przez Państwo. Przeprowadzone na przykładzie czterech grup gospodarstw rolnych badania przybliżają nas do odpowiedzi na pytanie jak usprawnić krótkookresowa politykę ekonomiczną celem stymulowania mechanizmu rynkowego dla długookresowego rozwoju sektora. Wykorzystując dane polskiego FADN z lat 2008-2019 autorzy badania zastosowują zmodyfikowaną metodę PSM dla określenia efektów ekonomicznych zmian zachodzących w gospodarstwach rolnych. Dowodzą, że źródłem długotrwałego rozwoju i sukcesu ekonomicznego są efektywne inwestycje. Wskazują równocześnie, że podmioty gospodarcze optymalizując swoją mikroekonomiczną funkcję celu dostosowują inwestycje do celów pomocy publicznej, czym obniżają efektywność wykorzystania środków finansowych.

Słowa kluczowe: efektywność polityki rolnej, inwestycje w rolnictwie, rozwój gospodarstw rolnych, polityka rolna

JEL Codes: Q12, Q18, O13,

Information about the authors:

prof. assoc. Marek Wigier, PhD, IAFE-NRI

Institute of Agricultural and Food Economics - National Research Institute, Warsaw

e-mail: marek.wigier@ierigz.waw.pl

ORCID: 0000-0001-5134-2295

prof. assoc. Marian Podstawka, PhD

Warsaw University of Life Sciences - SGGW

e- mail: marian podstawka@sggw.edu.pl

ORCID: 0000-0002-3834-0743 